\title{
DISCIPLINARY RESPONSIBILITY'S APPLICATION TO THE LOCAL GOVERNMENT EMPLOYEES VIOLATING THE ANTI-CORRUPTION LEGISLATION IN THE RUSSIAN FEDERATION, EUROPE AND THE UNITED STATES OF AMERICA
}

\author{
HUGO FLAVIER, \\ University of Bordeaux (Bordeaux, France) \\ IRINA CHIKIREVA, \\ Tyumen State University (Tyumen, Russia) \\ KSENIYA IVANOVA, \\ Tyumen State University (Tyumen, Russia)
}

DOI: 10.21684/2412-2343-2017-4-4-116-144

This paper considers issues of legal regulation of moral condemnation of municipal officials and the impact of the recommendations of the Group of States against Corruption (GRECO) on the system of legal regulation of counteraction to Russian corruption. It also examines the concept and principles of anti-corruption, the grounds and procedure for bringing disciplinary proceedings against municipal officials for violating of anticorruption duties as well as issues of compliance with the rules of the Federal laws of the Russian Federation "On Combating Corruption" and "On Municipal Service in the Russian Federation," and the necessity to unify their content concerning the reasons for dismissal due to the loss of confidence in municipal and state officials for corruption offenses. The Model Code of Ethics and Official Conduct of Civil Servants of the Russian Federation and Municipal Officials is useful to defining the legal status of moral condemnation, the shape of its issuance, scope, duration and legal implications of the use.

Keywords: corruption; GRECO recommendations; disciplinary responsibility and moral condemnation of municipal employees; corruption offenses.

Recommended citation: Hugo Flavier et al., Disciplinary Responsibility's Application to the Local Government Employees Violating the Anti-Corruption Legislation in the Russian Federation, Europe and the United States of America, 4(4) BRICS Law Journal 116-144 (2017). 


\section{Introduction: \\ The Impact of the Group of States against Corruption (GRECO) upon Anti-Corruption Legal Regulatory Systems in the Russian Federation}

The authors of this work believe that it is necessary to analyze the impact of the Group of States against Corruption (GRECO) upon Russia, tracing the historical development of Russian anti-corruption legislation. By comparing the anti-corruption experiences of countries like the United States of America and France, the authors aim to clarify the pros and cons of existing legal traditions and make predictions as well as recommendations.

It is universally acknowledged that corruption is harmful to a state's prosperity and that the international community must work to combat it on a global level. States - participants of the United Nations Convention against Corruption (2003) are concerned about the seriousness of problems and threats posed by corruption to the stability and security of societies. These include the undermining of the democratic institutions, ethical values and justice as well as the jeopardizing of sustainable development and the rule of law. States are also concerned about corruption cases that involve vast quantities of assets, particularly those that may constitute a substantial proportion of state resources, as well as those that threaten the political stability and sustainable development of those states. International society is convinced that corruption is no longer a local matter but a transnational phenomenon that affects all societies and economies, making international cooperation to prevent and control it essential. It is clear that only a comprehensive and multidisciplinary approach is required to prevent and combat corruption effectively.

All societies face the problem of preventing and addressing corruption in its governmental entities, especially at the local level where systemic issues like organized crime take root. Corruption in local governments, by elected officials or public employees, is an unfortunately frequent reality in both developing and developed countries. The negative consequences of corruption include rising governmental costs, unenforced legal regulations, potential endangerment of public health and safety, and reduced accountability. More specifically, corruption costs local governments both directly in terms of missing revenue and indirectly in terms of increased taxes and interest payments. Social costs include a loss of public confidence by taxpayers within their own government, and increased resentment by those who must continue to comply with the laws and rules while others are accorded special treatment.

Thus, we can submit that the problem of corruption cannot be underestimated. In plenty scientific articles is underlined that in order to operate effectively, public institutions must also inspire confidence in the people they serve. Thus, there is a significant negative correlation between corruption and confidence in public 
institutions. The most negative result of corruption is that it leads to a future eroding confidence in public institutions.'

It is believed, that local corruption arises from structural factors within three levels: the central-local level (relations between local authorities and the central government); the local-local level (competition between local authorities) and the intra-local level (factors relating to the performance of local councils and local democracy). ${ }^{2}$

At local level, one common understanding of the danger of corruption is that it can shake the foundations of local governance. We agree with the assertion especially that this type of criminal behavior from the local servant threatens the logic of the parliamentary chain, and, therefore, it threatens democracy itself.

To conclude, in Russia we need to find the effective instruments to combat acts of corruption at local level with the cooperation and support of the global community. Also it is required to solve the issue of contradictions between Russia and GRECO on the types of responsibility and the rule of criminal liability for acts of corruption, and to unify disciplinary actions. Additionally the content of the basis for dismissal of municipal and government officials must also be uniform in order to minimize loss of confidence because of corruption offences. Within the process of law enforcement and judicial practice emerges questions about the legal status of moral condemnation of municipal employees, the normative act, which it introduces, in any form can be made moral judgment (oral or written), what the consequences are, expiration date and whether it is possible to challenge it?

Firstly, we have to clarify types of possible misconduct at the municipal level. Types of misconduct are the following:

Bribery - the offering, giving, receiving, or soliciting of any item of value to influence the actions of an official or other person in charge of a public or legal duty. Taking money to give people preferential treatment, identified areas of concern include bribes from developers in permitting process, payback for zoning decisions, equipment contracts, or service contracts, bribery of building inspectors to obtain permits, bribery of elected officials for development variances and approvals, bribery of planning staff to obtain recommendations for development approvals - may take the form of inappropriate gifts/sponsorship such as hockey tickets and other gifts for politicians and (or) staff.

Nepotism/Cronyism - cronyism may include awarding contracts to people affiliated with the municipality or corrupt official, patronage appointments based on connections rather than qualifications, awarding contracts at inflated prices, ${ }^{3}$

\footnotetext{
Such articles as: Bianca Clausen et al., Corruption and Confidence in Public Institutions: Evidence from a Global Survey, 25(2) The World Bank Economic Review 212 (2011); Olayinka Akanle \& Jimi O. Adesina, Corruption and the Nigerian Development Quagmire: Popular Narratives and Current Interrogations, 31(4) Journal of Developing Societies 421 (2015).

5 Itai Beeri \& Doron Navot, Local Political Corruption: Potential Structural Malfunctions at the Central-Local, Local-Local and Intra-Local Levels, 15(5) Public Management Review 712 (2013).

6 Black's Law Dictionary (B. Garner (ed.), $9^{\text {th }}$ ed., St. Paul, MN: West Group, 2009).
} 
nepotism may include such issues as favoring family members in municipal hirings, zoning regulation changes based on friendships among colleagues rather than disinterested analysis.

Embezzlement - misappropriation of money or resources under a local government official or employee's control.

Fraud - making false claims for benefits in order to abuse systems such as social security extortion - occurs when a public official forces someone to give them benefits in exchange for acting/not acting in a particular way, or when an external actor does the same to a public official.

Conflicts of interest - a personal interest in a matter that goes beyond the interests of other members of the community, and might reasonably be expected to influence the elected official's performance of his or her duties, e.g. close links between developers and city staff, campaign contributions from developers, conflict in contract awards, personal interest in administrative decisions.

Breach of duty - local government officials and employees ignoring applicable municipal legislation, e.g. sale of municipal assets for less than market value misuse of authority - lack of transparency/democratic concerns such as inappropriate use of in-camera meetings, non-public altering of official records, dishonesty concerning legislative options fraudulent use of expense accounts such as reimbursing inappropriate expenses, double expensing - influence on independent third party bodies, such as boards, which are intended to be at arm's length.

Criminal activity - including organized crime, internal theft/fraud, petty theft/fraud.

Perhaps one of the most obvious and yet most consistently recurring corruptionrelated problems for local governments is conflicts of interest, possibly due to the many and varied circumstances in which such conflicts may arise. The prevalence of this type of corruption is demonstrated by the amount of legal authority and law cases available on the topic.

Russia cooperates with the Council of Europe in the framework of the project RUCOLA 2, aimed at developing legislation to combat corruption, in which Drago Kos, Chairman of the Commission for the Prevention of Corruption in the Republic of Slovenia and former Chairman of GRECO stated that

there is no country where there is no corruption - politicians, public servants, business leaders, journalists and neighbors - all infected with the social disease... First of all, governments and international organizations need to understand that corruption is a very dangerous phenomenon. Only then the interest in the need for effective national and international legislation, programs and measures comes. ${ }^{4}$

\footnotetext{
Кос Д. Опыт европейских стран в области разработки и функционирования антикоррупционных стратегий [Drago Kos, The Experience of European Countries in the Development and Functioning of AntiCorruption Strategies] in Россия - Европа вместе против коррупции. Ч. 2 [Russia-Europe Together against Corruption. Part 2] 144 (Oct. 6, 2017), available at http://www.coe.int/t/dg1/legalcooperation/ economiccrime/corruption/Projects/RUCOLA-2/RUCOLA\%202_publication2.pdf.
} 
Some effective steps in this direction were made especially in 2007 when Russia became a member of GRECO, the purpose of which is to improve the ability of Member States to fight corruption by monitoring the compliance with the commitments acquired in this field, using the processes of evaluation and monitoring.

GRECO created recommendations on anti-corruption matters, which have to be applied in the Russian Federation. It is clear that such international activity has a valuable impact on the legal systems and anticorruption efforts in the Russian Federation especially in the field of disciplinary responsibility for municipal officials who engage in corruption.

In Addendum to the Compliance Report on the Russian Federation adopted by GRECO at its $58^{\text {th }}$ Plenary Meeting (Strasbourg, 3-7 December 2012) ${ }^{5}$ GRECO states that recommendations have only been partially implemented and that legislative reforms still remain incomplete. Therefore, GRECO reiterated its position, expressed in para. 59 of the Evaluation Report, that a meaningful evaluation of the real impact of various anti-corruption measures necessitated the development of different tools and that measures implemented could not be assessed until they had taken full effect.

To improve the anti-corruption institutional framework the Russian Federation promoted the Decree of the President of the Russian Federation of 11 April 2014 No. 226 "Concerning the National Anti-Corruption Plan for 2014-2015."' It was aimed at ensuring the enforcement of legislation and administrative decisions in the field of combating corruption in accordance with the National Strategy for countering corruption and intensifying anti-corruption citizens' education and scientific research. Furthermore, the National Anti-Corruption Plan for 2016-2017 was created to provide tougher penalties for corruption-related crimes.

The Russian Federation has also established a system of regulations on anticorruption within its regions and municipalities. For example, the Tyumen region of the Russian Federation adopted a regional target anti-corruption program (plan) for 2012-2015 and a master plan to counter the local government corruption.

The relevant regulations were approved within the city of Tyumen, as well as in other cities of the Russian Federation. These complex regulations on anticorruption are publicly available on the official websites of public authorities and local governments. Thus, in the Russian Federation anti-corruption regulations have

\footnotetext{
Available at http://www.coe.int/en/web/greco/evaluations/russian-federation.

6 Указ Президента РФ от 11 апреля 2014 г. № 226 “О Национальном плане противодействия коррупции на 2014-2015 годы," Собрание законодательства РФ, 2014, № 15, ст. 1729 [Decree of the President of the Russian Federation No. 226 of 11 April 2014. Concerning the National Anti-Corruption Plan for 2014-2015, Legislation Bulletin of the Russian Federation, 2014, No. 15, Art. 1729].

Закон Тюменской области от 25 февраля 2009 г. № 6“О противодействии коррупции в Тюменской области" [Law of the Tyumen region No. 6 of 25 February 2009. On Anti-Corruption in the Tyumen Region] (Oct. 6, 2017), available at https://admtyumen.ru/ogv_ru/gov/adm_reform/more.htm?id= 10457443@cmsArticle.
} 
been comprehensively adopted at the federal, the regional and municipal levels. Such regulations are strategically important in case of anti-corruption cooperation between law enforcement bodies and citizens.

Such measures have led to improving the partnership between people and official bodies. In recent years, citizens have become more active in using Internet resources because their appeals immediately go to the prosecuting authorities, while sending written papers by post takes a long time.

To conclude, the recommendations of GRECO have a significant impact on the system of legal regulation of counteraction to corruption of the Russian Federation.

\section{The Concept of Corruption and Anti-Corruption, Anti-Corruption Principles}

There is no universally accepted definition of "corruption." Definitions applied to corruption vary from country to country in accordance with cultural, legal or other factors and the nature of the problem as it appears in each country. ${ }^{8}$

GRECO analyzed the Federal law "On Combating Corruption"s and the Code of Administrative Offences of the Russian Federation ${ }^{10}$ and announced that on the one hand, GRECO was reassured that the only type of offence of a corrupt nature for which the laws of the Russian Federation envisaged administrative liability of a natural person was "illegal reward" (compensation) from a legal entity, pursuant to Art. 19.28 of the Code of Administrative Offences. On the other hand, it remained concerned that Art. 13 of the Federal law "On Combating Corruption" remained unchanged and stipulated that individuals who commit corruption offences could be brought not only to criminal but also to administrative or civil proceedings and liability for corruption. It was concluded that the general definition of corruption, as contained in the Federal law "On Combating Corruption," may not have a decisive effect upon the selection of criminal or administrative proceedings and even if, in theory, the criminal justice process was to be given priority, the existence of two parallel procedures in respect of corruption offences afforded opportunities for manipulation.

As a result of such conclusions, GRECO recommended to review Russia's system of administrative and criminal procedures in order to firmly establish that cases of corruption are to be treated as criminal offences as a main rule.

8 UN Guide for Anti-Corruption Policies (November 2003) (Oct. 6, 2017), available at https://www. unodc.org/pdf/crime/corruption/UN_Guide.pdf.

9 Федеральный закон от 25 декабря 2008 г. № 273-Ф3 “О противодействии коррупции,” Собрание законодательства РФ, 2008, № 52 (ч. 1), ст. 6228 [Federal law No. 273-FZ of 25 December 2008. On Combating Corruption, Legislation Bulletin of the Russian Federation, 2008, No. 52 (part 1), Art. 6228].

10 Кодекс Российской Федерации об административных правонарушениях от 30 декабря 2001 г. № 195-Ф3, Собрание законодательства РФ, 2002, № 1 (ч. 1), ст. 1 [Code of Administrative Offences of the Russian Federation No. 195-FZ of 30 December 2001, Legislation Bulletin of the Russian Federation, 2002, No. 1 (part 1), Art. 1]. 
Russian authorities now report that, on 30 September 2011, the Prosecutor General's Office forwarded to the Ministry of Justice proposals regarding a modification to be introduced in the existing anti-corruption legislation. In particular, it was suggested that a new principle of counteracting corruption be added in order to ensure a clearer distinction between administrative offences and criminal corruption offences. The distinction is made in the following manner: Art. 3 of the Federal law "On Combating Corruption" was to be supplemented by provision 3.1 stipulating that "manifestations of corruption are to be classified, as a main rule, as criminally punishable acts." The authorities contend that the introduction of this new principle would facilitate a clearer distinction between administrative and criminal liability for corruption offences and ensure that those guilty of corruption are prosecuted, as a main rule, under the relevant provisions of the Criminal Code. Having obtained consent from the Ministry of Justice, at the end of 2011, the Prosecutor General's Office has sent the above mentioned draft to the State Duma (i.e. lower chamber of the Parliament).

Russia has made a significant step towards strengthening the framework of its anti-corruption legislation, aligning it with the best practices recognized at the international level, including the UK Bribery Act and the U.S. Foreign Corrupt Practices Act. Article 13.3 of the Anti-Corruption Law requires organizations to develop and implement anti-corruption measures such as (i) appointing a specific department or an official to be responsible for preventing corruption and related offences; (ii) cooperating with enforcement authorities; (iii) developing and implementing standards and procedures for ethical business practices; (iv) establishing an ethical code of conduct for personnel; ( $v$ ) preventing and resolving conflicts of interest; and (vi) preventing the filing of false or off-the-record reports and the use of forged documents. Russia also joined the OECD Anti-Bribery Convention in $2012^{11}$ and had the G20 Presidency in 2013, where fighting corruption was one of three main issues on the agenda. Companies should therefore actively ensure that they stay compliant with the new amendment to the Anti-Corruption Law.

Comparing Russian experience with the rest of the world it is obvious that most countries of the European and Asian regions have implemented anti-corruption laws. For example, the UK Anti-Corruption Plan ${ }^{12}$ was implemented at December 2014, which sets out the actions government will take to. It works to make it harder for criminals in the UK to use corruption to carry out their crimes and to strengthen the integrity of institutions across the public and private sectors. It also aims to make best use of the UK's position as a leading international aid donor and a global centre for trade and investment to re-enforce the global fight against corruption as well as

11 OECD Convention on Combating Bribery of Foreign Public Officials in International Business Transactions, 17 December 1997, 37 I.L.M. 1 (Oct. 6, 2017), available at http://www.oecd.org/daf/ anti-bribery/ConvCombatBribery_ENG.pdf.

15 The UK Anti-Corruption Plan (December 2014) (Oct. 6, 2017), available at https://www.gov.uk/ government/uploads/system/uploads/attachment_data/file/388894/UKantiCorruptionPlan.pdf. 
stamp out bribery and corruption; and raise global standards. In the context of the aforementioned Plan a "corrupt" practice is defined as "offering, giving, receiving or soliciting, directly or indirectly, of anything of value to influence improperly the actions of another party."

In the UK Anti-Corruption Plan the high importance of local government protection is underlined. Local governments are targeted by those who wish to corrupt local processes, such as housing or planning, for their own gain; and organized crime groups are known to target local officials to consolidate their status in communities. That can damage the reputation of localities and undermine an ability to promote sustainable local lands growth.

The German Anti-Corruption Act is contained in the Criminal Code, its provisions were last revised in $1997 . .^{13}$ This statutory framework prohibits bribery of public officials and in private business transactions, and addresses both active and passive bribery. Prosecutors sometimes bring additional charges, such tax evasion, against those accused of bribery. The German Anti-Corruption Act delineates two types of bribery: (1) granting a benefit (Vorteilsgewährung) to influence the official in his or her duties; and (2) offering a bribe (Bestechung) in order to induce an outright violation of official duties, which earns harsher penalties.

Such an approach to the regulation of corruption counteraction is typical for most countries of Eastern Europe, because in Central and Eastern Europe, the strong motivation of many countries to join the European Union prompted the adoption of various anti-corruption laws. Introduction of asset declarations can be an easy way for governments to demonstrate their determination to do something about the problem of corruption. ${ }^{14}$ Of course that makes national anti-corruption acts similar.

If we compare Russian anti-corruption legislation with that of Britain and Germany, Russian law prohibits both public and commercial bribery and contains provisions addressing giving bribes, receiving bribes and acting as an intermediary for bribes, as other domestic corruption counteracting acts do.

In recent legislative developments, Russia's progress toward integration into the global community, and its continuing efforts to counteract corruption at all levels: federal, regional and local - may suggest that the government is ready to crack down on the corruption prevalent in so many sectors. Therefore, a serious problem with corruption exists in Russia, but we suppose that the Russian government in the near future will find ways to implement effective solutions to reduce corruption, especially at the local level.

16 Gesetz zur Bekämpfung der Korruption (KorrBekG - Anti-Corruption Act), Strafgesetzbuch (STGB German Criminal Code), 19 August 1997, Bundesgesetzblatt (BGBI.) I at 2038, §§ 331-35 (Ger.) (Oct. 6, 2017), English translation available at http://www.gesetze-im-internet.de/englisch_stgb/index.html.

17 OECD, Asset Declarations for Public Officials: A Tool to Prevent Corruption, OECD Publishing (2011) (Oct. 6, 2017), available at http://dx.doi.org/10.1787/9789264095281-en. 


\section{The Grounds and Procedure for Bringing Municipal Officials to Disciplinary Responsibility for Corruption Offenses in the Russian Federation}

It is clear that there is a need for improvement of legal regulations due to the problems arising from holding municipal officials accountable for corruption offences.

The problem of municipal employee compliance of anti-corruption duties defined by the Federal law"On Combating Corruption" and Federal law"On Municipal Service in the Russian Federation"15 is the most evident. However the problem of the application of the moral condemnation for corrupt municipal employees is also important.

According to Art. 3 of the Federal law "On Municipal Service in the Russian Federation," on local government officers action of the labor law with the features provided by this Federal law extends.

In Art. 192 of the Labor Code of the Russian Federation ${ }^{16}$ it is stated that for committing disciplinary delinquency, i.e. for employee's non-execution or improper execution, through his own fault, of his professional duties the employer is entitled to impose upon him the following disciplinary penalties: reprimand; reproof; dismissal on the applicable ground.

When imposing a disciplinary penalty, the gravity of the offense and the circumstances under which it was made should be taken into account.

Nonetheless, before imposing a disciplinary penalty upon the employee, the employer may demand him to write an explanation. If the employee refuses to submit such an explanation, a statement is drawn up.

However, the Labor Code alone does not regulate the procedure of municipal servants' disciplinary penalties, but the Federal law "On Municipal Service in the Russian Federation."

Article 27 of the Federal law states that for a disciplinary delinquency - municipal employee's non-execution or improper execution, through his own fault entrusted to him duties - the representative of the hirer (employer) has the right to apply the following disciplinary penalties: reprimand; reproof; dismissal from the municipal service.

A municipal employee that committed a disciplinary offense may be temporarily (but not more than one month), dismissed from duty with the preservation of salaries before focusing on his disciplinary responsibility.

Thus, Federal law extends the provisions of the Labor Code.

18 Федеральный закон от 2 марта 2007 г. № 25-Ф3“О муниципальной службе в Российской Федерации," Собрание законодательства РФ, 2007, № 10, ст. 1152 [Federal law No. 25-FZ of 2 March 2007. On Municipal Service in the Russian Federation, Legislation Bulletin of the Russian Federation, 2007, No. 10, Art. 1152].

19 Трудовой кодекс Российской Федерации от 30 декабря 2001 г. № 197-Ф3, Собрание законодательства РФ, 2002, № 1 (ч. 1), ст. 3 [Labor Code of the Russian Federation No. 197-FZ of 30 December 2001, Legislation Bulletin of the Russian Federation, 2002, No. 1 (part 1), Art. 3]. 
In case of counteracting corruption at the municipal level, in the Federal law above mentioned an amendment was included: Art. 27.1. This Article declares that if a municipal employee does not observe the restrictions and prohibitions or refuses to regulate competitive interests or if he do not execute his duties established disciplinary penalties will be applied in order to counter corruption.

In the application of penalties, authorities must consider the nature of the committed corruption offense, the circumstances under which the crime was committed. Furthermore, they should consider the municipal employee's past observance to his professional duties.

The act of applying disciplinary action to the municipal employee in the event of corruption offense must include the purpose of a disciplinary penalty. Many countries, including New Zealand, Australia, the U.S., etc., that had adopted more managerial styles of public management, have passed new or renewed codes for their public servants. Also, the Committee of Ministers of the Council of Europe had issued the Model Code of Conduct for Public Officials, prepared by the Multidisciplinary Group on Corruption (GMC). ${ }^{17}$ After a year, in September 2001 the European Ombudsman approved the Code of Good Administrative Behaviour. ${ }^{18}$

Nowadays governments in transitional societies are beginning to recognize the importance of officials' ethical conduct on a day-by-day basis. This is shown in the newly adopted acts of public service, laws on conflict of interest, anticorruption strategies, and codes of conduct or ethical codes that regulate disciplinary liability of public and municipal servants.

For example, the Act No. 159/2006 on Conflict of Interests ${ }^{19}$ has a separate article on reporting of improper activities, which require reporting cases of improper use of financial resources, equipment and services, fraud, or corruption. The Code provides the possibility to refuse to act illegally and report this fact to the superior.

The Bulgarian Civil Servant's Code of Conduct ${ }^{20}$ mentions only one sanction for breaching the rules laid down in the document - resignation from the civil service. Such an extreme measure may witness the wish to regulate the activity and at the

20 Model Code of Conduct for Public Officials, Recommendation Rec.(2000)10, adopted by the Committee of Ministers of the Council of Europe on 11 May 2000 (Oct. 6, 2017), available at https://wcd.coe.int/ com.instranet.InstraServlet?command=com.instranet.CmdBlobGet\&InstranetImage $=532006 \&$ SecM ode $=1 \&$ Docld $=343460 \&$ Usage $=2$.

18 European Code of Good Administrative Behaviour, adopted by the European Parliament on 6 September 2001 (Oct. 6, 2017), available at https://osha.europa.eu/en/about/good-administrativebehaviour/annex1-european-ombudsman-code-of-good-administrative-behaviour.pdf.

22 Act of Law No. 159/2006 Coll., of 16 March 2006, on Conflict of Interests (Oct. 6, 2017), available at http://www.psp.cz/en/docs/laws/2006/159.html.

23 Bulgarian Code of Conduct of State Administration Employees, adopted with CoM Decree No. 126/ 11.06.2004, promulgated, SG No. 53/22.06.2004 (Oct. 6, 2017), available at https://www.unodc. org/documents/treaties/UNCAC/WorkingGroups/workinggroup4/2012-August-27-29/Responses_ NVs_2012/20120419_Bulgaria_English_3.pdf. 
same time to discourage incompatible conduct. It would be wiser to differentiate the sanctions according the importance of breached principle.

The Latvian Code mentions the obligation of a civil (municipal) servant to prevent unlawful action with mentioned principles in an organization and in public administration. After receiving an assignment that is in conflict with principles of ethical behavior, a civil (municipal) servant must inform supervising official who has the responsibility to make a corresponding decision. If a civil (municipal) servant in his/her actions does not observe the principles of behavior of civil (municipal) servants, any person or organization has a right to submit a complaint to the head of corresponding institution. It is the responsibility of the head of institution to consider the complaint and decide if a disciplinary investigation should be initiated against the civil servant in question. Though the Code does not mention concrete sanctions, the disciplinary liability may be the issue of internal institutional rules.

The Slovakian Draft Code of Ethics for Civil Servants establishes a disciplinary liability: reprimand or reduction of their salary by $15 \%$ up to 3 months, termination the employment relation with the employee on grounds of severe or repeated violations of the Code.

However, Jure Škrbec and Bojan Dobovšek ${ }^{21}$ both notice that legal education is likely affected by corruption influencing rule of law in Slovenian local selfgovernments, where everyone (especially mayors) attempts to avoid obligations and find loopholes into the law in order to benefit.

There is a common belief that such illegal behavior and the negative consequences to the rule of law are fundamentally due to human greed and the role of informal networks. Therefore, the Slovenian government has started a process to toughen laws against corruption and violations of the Code of Ethics.

In Canada, in addition to the common law and the Criminal Code, provincial legislation contains conflicts of interest laws for municipal governance. Legislative conflicts of interest laws attempt to deal with the problem by disqualifying a person from seeking or holding office who has a major conflict of interest or by codifying the common law relating to fiduciaries.

Part Four of the Community Charter, along with the Criminal Code, broadly governs municipal corruption in British Columbia. Municipal officers are subject to a Code of Ethics, and most municipalities have instituted their own Code of Conduct for elected officials. Avenues for official corruption-related investigation in $\mathrm{BC}$ include the following:

- complaint to an auditor, triggering an investigation by the auditor - complaint to the Inspector of Municipalities, who has the powers of an inquiry officer under the Inquiry Act;

- council or committee inquiry within the local government, with the powers of an inquiry officer under Inquiry Act;

24 Jure Škrbec \& Bojan Dobovšek, Corruption Capture of Local Self-Governments in Slovenia, 11(3) Lex Localis - Journal of Local Self-Government 615 (2013). 
- investigation by the RCMP or local police force in the case of alleged indictable crimes or summary conviction offences - investigation by the Ombudsperson, who is expressly empowered to examine administrative fairness within local governments;

- investigation by the New Municipal Auditor General, who has wide powers of inquiry - court proceeding initiated by ratepayers/electors under the Criminal Code.

In the USA according to a specific decentralized legislation system, the liability level written in Ethic Codes depends of the state. Some states specify that violations of the state's ethics law are also violations of criminal law and impose penalties accordingly. Other states have statutes, in addition to or in place of ethics laws, which are in the state's penal or criminal codes and cover similar behaviors.

For example, in Ethic Code of Alabama includes more than 20 positions of intentional violation of the Code of Ethics for Public Officials and Employees, such as use of official position or office for personal gain, use or disclosure of confidential information gained in the course or by reason of their position for personal financial gain, actions of former public officials or public employees prohibited for two years after departure etc. Also Alabama has one of the most strict penalties for such delicts mentioned above - they are considered as Class B felony and are punished by maximum imprisonment for $2-20$ years; maximum fine $\$ 30,000 .^{22}$

On the contrary, in Arkansas misuse of confidential information is only a misdemeanor and is punished for max. imprisonment of 1 year; maximum fine $\$ 2,500$. Some violations such as receiving a gift or compensation for the performance of the duties and responsibilities of his official position or purposely use or disclose to any other person or entity confidential government information acquired in the course of official duties, bribery or disclosure of confidential governmental information do not have criminal consideration and are punished by written warning for the first violation and are fined about $\$ 50-\$ 2,000$ for second and subsequent violations. ${ }^{23}$

In New Jersey, most delicts are stated in Criminal Codes, but the government defines within the Ethic Codes disclosure or use of information not available to the public for personal as misconduct. The maximum fine for such misbehavior is $\$ 500-$ $\$ 10,000$ alongside an additional punishment - of suspension from office for 1 year. If the offence is decided to be willful and continuous disregard of ethical regulations, they may be removed from office completely and may barred from holding any public office in the state for a 5 -year period. ${ }^{24}$

25 Code of Ethics for Public Officials and Employees of Alabama (Oct. 6, 2017), available at http://ethics. alabama.gov/docs/GuidelinesPublicOfficialsEmployees7-2012.pdf.

26 Sample Code of Conduct for Arkansas Municipal Officials (April 2014) (Oct. 6, 2017), available at https:// www.google.ru/url? sa $=t \& r c t=j \& q=\& e s r c=s \&$ source $=$ web\&cd=8\&ved=0ahUKEwisyKTWjLfPAhVIVywK HQ5PCE0QFghTMAc\&url=https\%3A\%2F\%2Fstatic.ark.org\%2Feeuploads\%2Farml\%2FSample_Code of_Conduct_2014_WEB.pdf\&usg=AFQjCNEBPz_COo9sBOHIsIVJHyfFzxxuKg\&sig2=h5k_s7v18nr7GQ NypEelFg\&bvm=bv.134495766,d.bGg.

27 Local Government Ethics Law - State of New Jersey (Oct. 6, 2017), available at http://www.state.nj.us/ $\mathrm{dca} /$ divisions/dlgs/programs/ethics_docs/lgethics.pdf. 
Therefore, penalties for public corruption/violations of state ethics laws have many differences from state to state, however, they are generally stated both in Criminal Codes or (and) in Ethic Codes, and such violations are considered to be misdemeanor or felonies with penalties of imprisonment ranging from 3 up to 5 years or a fine.

\section{Issues Municipal Officials Accountability for Corruption Offenses in France}

The liability of municipal authorities has been gradually extended in France in keeping with the increased role of the state and has to a certain extend deviated from the legal developments of the common law countries, especially, the U.S. In France, where state liability is governed by the rules of public law to the largest extent, the departments and the communes were originally subjects to the rules of private law..$^{25}$ At the beginning of this century, however, the Tribunal des conflits held in the leading Feutry case $\mathrm{e}^{26}$ that in principle the liability of the departments and the communes is similar to that of the state.

The new tendencies went so far that the rules of state liability were extended to the associations syndical, chambers of commerce, etc., because they perform public economic services. This proves that not merely do state functions intrude into the private economic sphere but private economic services also assume public functions of an economic nature. That tendency has influenced to the legal position of municipal servants in France, because they started to account legal liability instead of civil responsibility.

Nowadays in France there are three main tiers of local administration: the commune, department and region. These are both districts in which administrative decisions made at national level are carried out and local authorities with powers of their own. Legally speaking, a local authority is a public-law corporation with its own name, territory, budget, employees, etc. and has specific powers and a certain degree of autonomy vis-à-vis central government. In addition, there are France's overseas territories and regional bodies (collectivités territoriales) with special status (Paris, Marseille, Lyon, Corsica, Mayotte and Saint-Pierre-et-Miquelon). ${ }^{27}$

The French public service consists of three main sections - State civil service (central administrations, regional and departmental services of the State, public establishments of the State), - territorial civil service (civil servants of the municipalities, departments and regions). The total number of public agents is

28 International Encyclopedia of Comparative Law. Vol. 6 (The Hague: Martinus Nijhoff Publishers, 1972).

26 Tribunal des conflits, 29 février 1908, Feutry, $n^{\circ} 00624$ (Rec., p. 208).

27 Republic of France, Public Administration Country Profile, Division for Public Administration and Development Management (DPADM), Department of Economic and Social Affairs (DESA), United Nations (April 2006) (Oct. 6, 2017), available at http://unpan1.un.org/intradoc/groups/public/ documents/un/unpan023308.pdf. 
approximately 4.8 million (officials, contractual agents, magistrates and military), of which 1.1 million for the territorial civil service. ${ }^{28}$

The current French civil service system is based on four civil service laws. Together these form the general civil service statute. The statute consists of a basic law providing for the rights and obligations of all civil servants as well as of three laws that relate to the three civil service groups. These laws concern the French State civil servants (la fonction publique de l'État), the public servants working in regional and local government (la fonction publique territoriale ${ }^{29}$ and the public servants working in the public hospitals, in particular nursing staff (la fonction publique hospitalière). Civil service law consists further mostly of government decrees. The central legal text that organizes the career of civil servants in France is the Civil Service General Statute $^{30}$ (CSGS). The CSGS applies to all civil servants. It embodies the rights and obligations of civil servants and emphasizes the concepts of career and hierarchy. Furthermore, particular statutes have also been developed for each corps, each a complement to the CSGS. They aim at organizing the career of civil servants within a corps. Dispositions include details about categories, classes and steps, promotion, performance evaluation disciplinary, etc., for that corps. Only few particular statutes derogate to the rules of the General Statute.

The structure of the French territorial civil service is characterized by its fragmentation, due to several factors. First, the large range of hiring bodies (local governments, branch offices, établissements publics). Second, within the State civil service stricto sensu (i.e., with tenure), corps, grading and hierarchy are precisely defined and strengthen the esprit de corps, while contract employees belong to another structure.

Civil servants are banned from any involvement in a company under the auspices of their department which would compromise their impartiality. Members of the French Government are required to make declaration of personal assets and submit it to the Commission for Financial Transparency in Politics. The Court of Accounts, or Cour des comptes, has responsibilities with respect to central government departments, ministries and agencies, etc., covering regularity and management audits. The Court is presided over by a Premier président who is appointed by a decree of the Council of Ministers and enjoys security of tenure. Inquiry commissions (or investigative committees) gather information and carry out investigation on a given issue. They are created by a vote in the Chamber concerned, and they may carry out investigation

28 Distribution of the Governmental Employees Working in France in 2013, by Sector (Oct. 6, 2017), available at https://www.statista.com/statistics/467844/distribution-civil-servants-sector-france/.

Loi $n^{\circ}$ 84-53 du 26 janvier 1984 portant dispositions statutaires relatives à la fonction publique territoriale (Version consolidée au 27 mai 2017) (Oct. 6, 2017), available at https://www.legifrance. gouv.fr/affichTexte.do?cidTexte=JORFTEXT000000320434\&fastPos=1\&fastReqld=225940823\&cate gorieLien $=$ cid\&oldAction=rechTexte.

30 Statut général des fonctionnaires, Le portail de la Fonction publique (Oct. 6, 2017), available at http:// www.fonction-publique.gouv.fr/statut-general-des-fonctionnaires. 
for a period of six months. A report is made public after completion of investigation. The hearings of the commissions are open to the public. Government activities can also be monitored by means of temporary information assignments, which may involve more than one committee. Information missions can seek information, hold hearings, and publish reports prior to the consideration of a policy or a Bill. They are smaller in scale than inquiry commissions. They touch on a variety of subjects, and serve as a forum for discussion, confrontation and conciliation.

The law on the prevention of corruption and on the transparency of public life and public procedures ${ }^{31}$ (March, 2016), has instituted a consultative committee charged with giving an opinion on the possibility of conflict of interest when a civil servant leaves his or her office to join a private firm. A ruling by the Council of State (6 December 1996, Société Lambda) has imposed a very strict interpretation of the law, to the extent that it is now extremely difficult to get the authorization to pantoufler in private companies with which the civil servant has had to deal in recent years.

Bribery and corruption, as part of the wider economic and financial criminality field, are under particular scrutiny since 2012 and the revelations of several highprofile cases, some involving top French public officials. As a consequence, recent reforms have hardened penalties and increased investigative powers.

The results of such trend are, at the moment, not visible through the final issues of proceedings but in the number of proceedings opened on those grounds. Bribery and corruption are dealt with by several offences, all contained in the Code penal ${ }^{\beta 2}$ which are mainly: corruption; influence peddling; illegal taking of interest; and favoritism in public procurement.

Public official corruption - whether French, foreign or international - and private corruption are criminal offences for both the corrupter ("active corruption") and the corrupted ("passive corruption") who can be prosecuted independently from one another.

Public official corruption is defined as:

- for anyone to propose, illicitly, directly or indirectly, any offer, promise, donation, gift or benefit to a public official (French, foreign or international) in order for he or she to carry out or abstain from carrying out an act pertaining to his or her office, duty, or mandate, or facilitated by his or her office, duty or mandate or to yield to a request of such kind by such public official ("active corruption," Arts. 433-1 and 435-3 of the Penal Code); and

- for a public official (French, foreign or international), to request or accept any offer, promise, donation, gift or benefit in order to carry out or abstain from carrying out an act pertaining to his or her office, duty, or mandate, or facilitated by his or her office, duty or mandate ("passive corruption," Arts. 432-11 and 435-1 of the Penal Code).

31 Transparency, Anti-Corruption and Economic Modernisation Bill: Introduction (March 2016) (Oct. 6, 2017), available at http://www.economie.gouv.fr/files/files/PDF/transparency-bill-march2016.pdf.

32 Code pénal (Version consolidée au 9 avril 2017) (Oct. 6, 2017), available at https://www.legifrance. gouv.fr/affichCode.do?cidTexte=LEGITEXT000006070719. 
Neither the performing of an act by the public official nor the actual payment of the bribe are needed for the offence to be constituted. "Active" and "passive" attempts at corruption are included in the offence definition and are therefore punishable. Hence, neither does it matter when the proposal or acceptance to pay or the request or acceptance of the payment occurs. The offence may be constituted whether they occur before or after the performing of the act or the abstention of the public official.

The main penalties for "active" and "passive" corruption, whether domestic or international, are 10 years' imprisonment and a fine of up to $€ 1,000,000(€ 5,000,000$ for legal persons) or up to twice the profits drawn from the offence.

Supplementary penalties are, notably:

- for natural persons: loss of civic, civil and family rights; disqualification from holding public office or any professional or social activity related to the infringement; prohibition to exercise an industrial or commercial activity (including managing a commercial company); and confiscation of the profits received by the corrupted; and

- for legal persons: prohibition to operate an activity related to the infringement; judicial supervision; exclusion from public procurement tendering; and confiscation of the objects used to commit the offence, the profits drawn from the offence or any unexplained wealth.

Corruption - as every major offence - is subject to a three-year statute of limitation (Art. 8 of the Code of Criminal Procedure ${ }^{33}$ ). This may sound a particularly short period, but French case law permits to postpone the starting point of the statute of limitation to the date where the facts appeared and could be observed under conditions enabling the exercise of the public action where they were concealed.

Unlawful taking of interest is twofold: it encompasses both interests held by French public officials when in charge of public duties and interests taken after the end of such.

At first, it is prohibited for French public officials, as previously defined, to take, receive or keep any interest in a business or business operation, either directly or not, when, at the time in question, it has had the duty of ensuring, in whole or in part, its supervision, management, liquidation or its payment. This offence is punishable by a five-year prison term and $\mathrm{a} € 500,000$ fine $(€ 2,500,000$ for legal persons), which may amount to twice the profit drawn from the offence (Art. 432-12 of the Penal Code). It is also prohibited for French public officials to take or receive an interest by the way of work, consulting or shares in one of the privately held companies which, within the framework of its duties, he used to supervise, entered into a contract with, formulated an opinion on such contract, or regarding which he proposed decisions to the competent authorities before the lapse of a three-year period following the end of these duties.

This offence also applies to third party companies when $30 \%$ of shares are held by one of the privately held companies mentioned in the previous paragraph, State-

33 Code de procédure pénale (Version consolidée au 22 mai 2017) (Oct. 6, 2017), available at https:// www.legifrance.gouv.fr/affichCode.do?cidTexte=LEGITEXT000006071154. 
owned companies operating in a competitive sector and subject to private law regulation, as well as joint-venture companies when the State and its components hold more than $50 \%$ of the capital.

This second offence is punishable by a three-year prison term and $\mathrm{a} € 200,000$ fine $(€ 1,000,000$ for a legal person), which may amount to twice the profits drawn from the offence (Art. 432-13 of the Penal Code). These offences aim to prevent French public officials from being placed in a situation where their personal interest contravenes or is likely to contravene the interest of the public good, which they are or were responsible for. The unlawful taking of interest stated in Art. 432-12 of the Penal Code embraces any kind of interests, whether material, intellectual, direct or indirect.

The mere fact of being placed in a situation where the personal interest is likely to contravene the interest of the public good can lead to a conviction, even if no harm or enrichment ensues from this offence, making this offence one of the most stringent in OECD countries regarding conflict of interest.

Defendants tried to challenge the constitutionality of Art. 432-12 of the Penal Code, but the case was dismissed by the French Cour de cassation on 19 March 2014. ${ }^{34}$ A legislative attempt to modify the definition of that incrimination also failed, on 22 January 2015, due to disagreement between the Senate and the National Assembly on a new wording of this incrimination. ${ }^{35}$ Unlawful taking of interest is subject to a similar postponement of the statute of limitation to the one described for corruption, when the criminal facts were concealed. ${ }^{36}$

Moreover, as the unlawful taking of interest may be a continuous offence (when the French Public Official keep an unlawful interest), the limitation period only starts the day the offence came to an end.

Between 2003 and 2013, the number of persons convicted for probity offences has been overall stable, with an average of nearly 300 per year. The average length of proceedings until a final decision is rendered is around five to six years. The penalties imposed (based on the analysis of convictions for only one offence) are mainly suspended imprisonment and fines, with an average, as an example, of around eight months and an $€ 8,000$ fine for corruption offences. Supplementary penalties, such as disqualifications and confiscations, are very rarely imposed. Although the figures are based on statistics of convictions for a unique offence, whereas important cases often imply multiple offence convictions (such as money laundering and misuse of company assets in addition to bribery and corruption), it is obvious that severe sanctions are rarely imposed until now. It can be noted that there has been a significant rise in the investigations targeting local public officials

34 Cour de cassation, criminelle, Chambre criminelle, 19 mars 2014, 14-90.001, Inédit.

35 Vote of the National Assembly on 22 January 2015, on the law proposal to "facilitate the exercise, by the local elected representatives, of their mandate."

36 Cour de cassation, criminelle, Chambre criminelle, 16 décembre 2014, 14-82.939, Publié au bulletin. 
for probity offences over the period 2008-2015 compared to the period 2001-2008 (a $70 \%$ rise in the number of targeted persons). ${ }^{37}$

The legislator introduced in 2016 a new process for self-reporting in corruption and influence peddling cases, similar to the system of repentance that applies for ordinary offences, such as drug trafficking. When the author or the accomplice of the offence has allowed the ceasing of the offence or the identification of the authors or accomplices, by repenting and warning the authorities, the prison sentence incurred is reduced by half (Art. 433-2-1 of the Penal Code).

The French Penal Code also contains a plea-bargaining process, which may theoretically apply to bribery and corruption cases since the abolition on 13 December 2011 of the restrictions to its scope (it now applies to every major offence, whereas it was previously confined to offences punishable by a five-year sentence at the most, and it is since applicable even at the end of an investigation conducted under the control of the investigating judge), which applied until then. But, to date, its implementation has been unsuccessful in white-collar crimes, leading Mr. JeanMichel Hayat, Paris High Court's President, to call, on 19 January 2015, for a "cultural revolution" by generalizing the recourse to this procedure in this kind of offences.

The first attempts failed, as in a recent case involving a major foreign bank for tax evasion and money laundering, where the bank is said to have refused the prosecuting authorities' proposal.

One of the major impediments affecting this procedure is that the French legal system only allows settlement in conjunction with a guilty plea, which may impact potential civil proceedings.

There is no deferred prosecution agreement in France, but, theoretically, criminal law provides for a judicial supervision of legal entities upon the activity in the exercise of which an offence was committed, after being convicted (Art. 131-46 of the Penal Code). This possibility is very rarely used.

The French legal system does not provide a special status for whistle-blowers but incorporates disparate provisions, which prevents layoffs as retaliation (Art. L1161-1 of the Labor Code ${ }^{38}$ regarding corruption and Art. 25 of the Act No. 2013-907 of 11 October 2013 on Transparency in Public Life ${ }^{39}$ regarding conflict of interest).

Various reforms were proposed by the CSPC, the High authority for public life transparency and by the United Nations Office on Drugs and Crime (the UNODC) and may lead to legislative change in the forthcoming years.

37 Phase 3 Report on Implementing the OECD Anti-Bribery Convention in France (October 2012) (Oct. 6, 2017), available at https://www.oecd.org/daf/anti-bribery/Francephase3reportEN.pdf.

38 Code du travail (Version consolidée au 12 mai 2017) (Oct. 6, 2017), available at https://www.legifrance. gouv.fr/affichCode.do?cidTexte=LEGITEXT000006072050.

39 Loi $n^{\circ}$ 2013-907 du 11 octobre 2013 relative à la transparence de la vie publique (Version consolidée au 28 mai 2017) (Oct. 6, 2017), available at https://www.legifrance.gouv.fr/affichTexte.do?cidTexte= JORFTEXT000028056315. 
Here are the most significant proposals made by these authorities: ${ }^{40}$

- setting-up an actual status for whistle-blowers: as stated before, the current regime only protects, through disparate provisions, employees that denounce criminal facts. The CSPC and UNODC call for the setting up of a general status for whistle-blowers, with a broader protection that encompasses every kind of retaliation (such as end of contracts for suppliers or customers, physical pressure on the whistle-blowers or their relatives...) and which provides fair and comprehensive compensation to its beneficiaries;

- improving the civil servant's reporting system, by the creation of a French authority similar to the UK's Serious Fraud Office, called the High authority for public life transparency;

- setting-up an impeachment process by allowing each legislative body to exclude one of its members in case of serious breach;

- ensuring that every conviction for breach of probity will be systematically sentenced by the ineligibility of the perpetrator; and

- expanding the limitation period from three to five years (for offences punishable by an imprisonment period of less than three years) or three to seven years (for offences punishable by an imprisonment period over three years) in order to bring the French limitation periods in line with those in most other European countries.

\section{Problems of the Legal Regulation of Moral Condemnation of Municipal Officials for Corruption Delicts}

The imperfection of regulatory duties creates problems for law enforcement in the process of ensuring disciplinary responsibility for municipal workers. As a result municipal officials in Russia are turning to the courts with the requirements for the restoration of the service. This thereby invalidates the Commission's decision to comply with the official conduct of civil servants and conflict of interest, the decision certifying commission as well as the order of dismissal and the order of the chief of the imposition of a disciplinary sanction. As noted in the article by N. Kolokolova "disciplinary responsibility of state and municipal employees in the light of jurisprudence (the substantive aspect)."

The Federal law "On Combating Corruption" identifies the following main responsibilities to comply with anti-corruption laws. In Art. 8 - the obligation of government and municipal employees to submit information on their incomes, property and property liabilities so as on incomes, property and property liabilities of their spouse (wife) and minor children. In Art. 9 - the duty of government and municipal employees to notify of approaches with a view to incite to corruption

40 Bribery \& Corruption 2016, France, Global Legal Insights, 16 November 2015 (Oct. 6, 2017), available at http://www.globallegalinsights.com/practice-areas/bribery-and-corruption/bribery-and-corruption. 
offences, and in the Art. 11 - the responsibility of prevention and settlement of conflicts of interest at the government and municipal service.

If we compare the Federal law "On Combating Corruption" with the Federal law "On Municipal Service in the Russian Federation," we see that Art. 12 of the later document requires municipal leaders and their family members to notify in writing his or her immediate superior any personal interest in the performance of official duties, that could lead to a conflict of interest. He must then take measures to prevent such a conflict. However, the obligation to notify not only the representative of the hirer (employer), but also the prosecuting authorities or other public authorities in all cases of appeals to a municipal from any person in order to induce him to commit corruption offense is not mentioned in Federal law "On Municipal Service in the Russian Federation." Such an obligation is stated only in the Art. 9 of the Federal law "On Municipal Service in the Russian Federation."

In case of such issues, GRECO recommended to the Russian Federation ${ }^{41}$ to elaborate and promulgate a model code of conduct/ethics for public employees/officials, including civil servants, which can be adjusted in light of the particular needs pertaining to different sections of public administration, and to ensure its implementation in practice, including offering adequate training to all staff concerned.

The Russian authorities now report that, on 23 December 2010, the Model Code of Ethics and Service Conduct for Public Officers of the Russian Federation was adopted by the Presidium of the Council for Counteracting Corruption. The Code is based on universally recognized principles and contains general ethical rules and conduct as laid down by the anticorruption legislation required for all citizens, public, and military officials. The experience drawn from the adoption of codes of ethics by such categories as judges, law enforcement officers, auditors, advocates/lawyers was used in the development of the Model Code. The authorities submit that the Model Code is aimed at regulating the norms of professional conduct and ethics, rendering assistance to public officials while complying with these norms and informing the citizens of the conduct that is to be expected from public officials.

Following the adoption of the Model Code, federal public authorities, public authorities of subjects of the Russian Federation and local self-government bodies have proceeded with the development and approval of their own codes of ethics and conduct and incorporated in the officials' labor agreements (contracts) the provisions on liability for violating the said codes. By mid-2012, codes of ethics have been developed by 55 federal public authorities, of which: 44 have been agreed with high ranking authorities, two have been sent to the Ministry of Justice for registration, two remain to be adopted shortly and two more have been finalized in view of the critical remarks provided by the Ministry of Justice. Additionally, 43 federal public agencies have introduced necessary changes to their service contracts and eight

\footnotetext{
41 Addendum to the Compliance Report on the Russian Federation, supra note 5.
} 
more have been completing this work. Moreover, Plenipotentiary Representatives of the President of the Russian Federation in the federal districts have organized work on the approval of codes of ethics and incorporation of the provisions on liability for violations of the codes in labor agreements (contracts) of public officials by public authorities of subjects of the Russian Federation and local self-government bodies.

The Model Code of Ethics and Official Conduct of Civil Servants of the Russian Federation and Municipal Employees, adopted on 23 December 2010 by the decision of the Presidium of the Presidential Council on Anti-Corruption (protocol No. 21) in para. 23 states an extra duty, compared with the Federal law "On the State Civil Service in the Russian Federation." ${ }^{42}$ It states that the state (municipal) employee endowed with organizational and administrative powers in relation to the other state (municipal) employees must take steps to ensure that subordinate state (municipal) employees are not allowed corrupt dangerous behavior, his personal conduct applies an example of honesty, fairness and justice.

The expansion of the list of anti-corruption duties is directly related to the liability for non-compliance. In para. 24 of the Model Code of Ethics and Official Conduct (Russia) is noted that the state (or municipal) employee endowed with organizational and administrative powers in relation to the other state (or municipal) employees, shall be liable in accordance with the Russian legislation for the acts or omissions of subordinate employees, violating the principles of ethics and rules of official conduct unless he has taken steps to prevent such acts or omissions.

Also para. 29 stipulates that the violation of the Moral Code provisions by municipal employees is a subject of moral condemnation declared at the meeting on the Commission for compliance with the requirements of official conduct of state (municipal) employees and conflict of interest, formed in accordance with the Decree of the President of the Russian Federation of 1 July 2010 No. 821 "On the Commission on Compliance with the Requirements of Official Conduct of State (Municipal) Employees and Conflict of Interest," and in the cases stipulated by federal laws, the violation of the provisions of the Model Code implies the use of a state (municipal) employee measures of legal responsibility.

This raises the question: what is the legal status of a moral judgment?

Article 6, para. 4 and Art. 9, para. 3 of the Federal law "On Combating Corruption" both contain a provision on alternative liability in the form of dismissal or application of other measures of legal responsibility against a person for corruption. This applies upon one's failure to provide information or for submitting deliberately false or incomplete information concerning their income, property and property obligations, as well as presentation of false information about income, property and property obligations

42 Федеральный закон от 27 июля 2004 г. № 79-Ф3“О государственной гражданской службе Российской Федерации," Собрание законодательства РФ, 2004, № 31, ст. 3215 [Federal law No. 79-FZ of 27 July 2004. On the State Civil Service in the Russian Federation, Legislation Bulletin of the Russian Federation, 2004, No. 31, Art. 3215]. 
of their spouse (wife) and minor children, and for failure to fulfill obligations to notify appeals in order to induce the commission of corruption offenses.

However, the violation of the Model Code of Ethics and Official Conduct is not mentioned as a reason to attract other measures of legal liability. Is it even possible for them to attribute moral condemnation? Or is it simply a special way to influence on municipal employee?

Attention should be paid to the fact that moral condemnation entails negative legal consequences, as in para. 29 of the Model Code of Ethics and Official Conduct where it is stated that officials' compliance with this document is considered for career advancement, as well as the implementation of disciplinary sanctions.

Thus, moral condemnation is legally uncertain, but at the same time it has allowed a measure of the impact on municipal employees for violating of the Model Code of Ethics and Official Conduct.

As researchers, we pose the following questions about the proper understanding of such punishment as moral judgment: what is the legal status of a normative act? In what form can a moral judgement be made, whether it is possible to challenge it? What are its limits, consequences, expire date?

As a method of combating corruption moral condemnation is hardly acceptable, because it does not apply to liability and the corruption offense should lead to more strict liability for the perpetrators. As a measure for violation of the rules of ethics and official conduct moral condemnation is uncertain in terms of legal regulation, it can produce negative consequences.

At the international level, particular attention is paid to protection from psychological violence at work also referred to as - "mobbing."

Article 26 of the European Social Charter ${ }^{43}$ of 3 May 1996 declares that in order to implement this right is prescribed to promote awareness, information and prevention of recurrent reprehensible or distinctly negative and offensive actions directed against individual workers in the workplace or in relation to work and to take all appropriate measures to protect workers from such conduct.

In paras. 26, 27 of the Model Code of Ethics and Official Conduct of Civil Servants of the Russian Federation and Municipal Officials it is noted that in official and personal conduct a municipal official refrains from:

a) any sort of statements and actions of discriminative nature by signs of gender, age, race, nationality, language, citizenship, social, property or family status, political or religious preferences;

b) rudeness, display of a disdainful tone, arrogance, preconceived remarks, wrong and unfair accusations;

c) threats, insulting expressions or remarks, actions impeding normal communication or provoking wrong conduct;

43 European Social Charter of 3 May 1996, European Treaty Series - No. 163 (Oct. 6, 2017), available at https://rm.coe.int/CoERMPublicCommonSearchServices/DisplayDCTMContent?documentld=090 $000168007 \mathrm{cf} 93$. 
d) smoking during office meetings, conversations or other office communication with citizens.

With their office conduct, the municipal officials are called to facilitate the establishment of businesslike relations and constructive collaboration with each other within the team.

At the same time, the moral condemnation declared at the meeting of the Commission on compliance with the requirements of official conduct of state (municipal) employees and conflict of interest is in the nature of public condemnation and can lead to stress among employees, psychological depression.

Consequently, a legislative resolution in a moral condemnation of his legal uncertainty could lead to an increase in international legislation banned psychological abuse at work (mobbing).

Thus, in the Model Code of Ethics and Official Conduct of Civil Servants of the Russian Federation and Municipal Employees it is advisable provide that moral condemnation is used only if it meets the requirements of the Code of Ethics. Legal uncertainty of that punishment demonstrates the need for improvement of legal regulation, the definition of its legal status and form of rendering, limits the period of validity and legal consequences.

\section{The Dismissal of Municipal Employees in Connection with the Loss of Confidence}

GRECO recommended that the Russian Federation review the current measures designed to prevent conflicts of interest in order to clarify their application scope in respect to public officials and their relatives. The goal is to remedy the shortcomings identified and to ensure that the necessary measures are fully implemented in practice.

GRECO notes that the main criticism, as outlined in para. 288 of the Evaluation Report, was directed at the insufficiently wide scope of rules aimed at preventing conflicts of interest (so as to cover the relevant public functions, officials and their close relatives) and, more importantly, at the lack of practical implementation of these provisions. The existing control mechanisms were also deemed to be weak; for example, the restriction in respect of post-employment ("revolving doors") was not subject to adequate control or legal consequences in cases of infringements.

Pursuant to the Federal law "On Amendments Made in Some Legislative Acts of the Russian Federation in Connection with Promoting State Management in the Area of Combating Corruption," ${ }^{\prime \prime 4}$ the loss of trust has been introduced as one of the

44 Федеральный закон от 21 ноября 2011 г. № 329-Ф3 “О внесении изменений в отдельные законодательные акты Российской Федерации в связи с совершенствованием государственного управления в области противодействия коррупции," Собрание законодательства РФ, 2011, № 48, ст. 6730 [Federal law No. 329-FZ of 21 November 2011. On Amendments Made in Some Legislative Acts of the Russian Federation in Connection with Promoting State Management in the Area of Combating Corruption, Legislation Bulletin of the Russian Federation, 2011, No. 48, Art. 6730]. 
grounds for the dismissal of a state or municipal official in case he or she fails to take measures to prevent (or resolve) conflicts of interest. Similarly, an executive official of the state or municipal service who fails to take measures to prevent (resolve) conflicts of interest by his or her subordinate may also be subject to dismissal. Furthermore, pursuant to the 2012-2013 National Anti-Corruption Plan, the Presidium of the Council for Counteracting Corruption and the federal state bodies, within the limits of their competence, have been mandated to detect conflicts of interest in case one of the parties thereto is a person occupying a state position of the Russian Federation and is appointed by the President or the Government or occupies a public position of "chief executive."The procedure for resolving conflicts of interest by senior public executives has been determined by the Decree of the President of the Russian Federation of 25 February 2011 No. 233.

As concerns the commissions set up by the Decree of the President of the Russian Federation of 1 July 2010 No. 821 "On Commissions for Controlling Compliance with the Requirements of Service Conduct by Federal Public Officials and the Settling of Conflicts of Interest" (see para. 102 of the Compliance Report), it is reported that, as of the end of 2011 , such commissions have been established by all federal public authorities and 3416 commissions have been set up by the authorities' territorial bodies. The strengthened observance of the conflicts of interest rules has brought about a significant increase in the number of disciplinary proceedings being initiated against federal state servants. Thus, the number of persons who were subject to disciplinary liability in 2010 was 556, as compared to 2232 in 2011 (or 4.4 times rise). For the period 2010-2011, the total number of public officers brought to disciplinary liability is 2788 .

According to Art. 27.1, part 2 of the Federal law "On Municipal Service in the Russian Federation"a municipal employee shall be subject to dismissal from municipal service in connection with the loss of confidence in the case of offenses established in Arts. 14.1 ("Conflict of Interest on Municipal Service") and 15 ("Information on Income, Property and Obligations of a Municipal Employee") of the Federal law.

In the Federal law "On the State Civil Service in the Russian Federation" amenities of dismissal on the base due to the loss of confidence is extended.

Article 59.2 of the Federal law mentioned above fixes that the public civil servant is subject to dismissal in connection with loss of trust in case of non-presentation of data on the income, expenses, on property and obligations of property character, and also on the income, expenses, on property and obligations of property character of the of the spouse (spouse) and minor children or submission of obviously false or incomplete information by it.

The representative of an employer who became aware of the occurrence of the civilian employee personal interest that results or may result in a conflict of interest, be dismissed due to loss of confidence in the event of failure of a representative employer's measures to prevent and (or) the settlement of a conflict of interest, a party which is subordinate civil servant. 
Various basic contents of dismissal of civil and municipal employees in connection with the loss of confidence are quite debatable, because Art. 6 of the Federal law "On Combating Corruption" as a corruption prevention measure provides for the introduction of anti-corruption standards. The value of these standards is highlighted in the research, that is the setting for the relevant field of activity a unified system of prohibitions, restrictions and permissions, to ensure the prevention of corruption in this area, as well as the unification of the law of state and municipal employees, and adjusts them to the restrictions, prohibitions and obligations.

Therefore, in order to implement the anti-corruption standards, it is advisable to unify the types of disciplinary sanctions and the content of dismissal grounds for the municipal and state employees. We suggest an addition to Art. 12 of the Federal law"On Municipal Service in the Russian Federation" the norms about official duties to notify not only the representative of the hirer (employer), but the prosecuting authorities or other public authorities all cases of appeals to it to any person in order to induce him to commit corruption offenses. The Model Code of Ethics and Official Conduct of Civil Servants of the Russian Federation and Municipal Officials needs to determine the legal status of moral condemnation, the shape of its delivery (oral or written), limits the period of validity, as well as to specify the legal consequences of moral condemnation, which will contribute to achieving the goals and objectives of the National Anti-Corruption Plan.

\section{Conclusion}

After the analysis of European and American legislation systems concerning corruption at the municipal level we can conclude that there are numerous types of political corruption that occur in local government. Some are more common than others, and some are more prevalent to local governments than to larger segments of government. Local governments may be more susceptible to corruption because interactions between private individuals and officials happen at greater levels of intimacy and with more frequency at more decentralized levels. Forms of corruption pertaining to money like bribery, extortion, embezzlement, and graft are found in local government systems. Other forms of political corruption are nepotism and patronage systems. ${ }^{45}$

Bribery is the offering of something which is most often money but can also be goods or services in order to gain an unfair advantage. Common advantages can be to sway a person's opinion, action, or decision, reduce amounts fees collected, speed up a government grants, or change outcomes of legal processes.

Extortion is threatening or inflicting harm to a person, their reputation, or their property in order to unjustly obtain money, actions, services, or other goods from that person. Blackmail is a form of extortion.

45 Daniel Treisman, The Causes of Corruption: A Cross-National Study, 76 Journal of Public Economics 399 (2000). 
Embezzlement is the illegal taking or appropriation of money or property that has been entrusted to a person but is actually owned by another. In political terms this is called graft which is when a political office holder unlawfully uses public funds for personal purposes.

Nepotism is the practice or inclination to favor a group or person who is a relative when giving promotions, jobs, raises, and other benefits to employees. This is often based on the concept of familism which is believing that a person must always respect and favor family in all situations including those pertaining to politics and business. This leads some political officials to give privileges and positions of authority to relatives based on relationships and regardless of their actual abilities.

Patronage systems consist of the granting favors, contracts, or appointments to positions by a local public office holder or candidate for a political office in return for political support. Many times patronage is used to gain support and votes in elections or in passing legislation. Patronage systems disregard the formal rules of a local government and use personal instead of formalized channels to gain an advantage.

Many local governments have an established political culture with certain expectations and practices that often determine what is seen as acceptable and not acceptable in local politics. In municipalities with an undeveloped or underdeveloped political culture, accountability and legitimacy is usually low and principles of ethics in government are not established. This can encourage corruption to take hold in the local government because citizens do not know what is considered corrupt, and local officials are not afraid to be corrupt because of the low accountability. In some places the local governments have been corrupt for so long that the citizens think that is how it is supposed to work because that is all they have been exposed to. Long periods of political instability will also lead to corruption in the government because people are unsure of how the government should operate, and thus do not know what practices are corrupt or how to stop them if they are corrupt.

Summing up international and Russian national experience we would like to admit that the Russian Federation's accession to GRECO, and the ensuing Russian system of evaluation and reporting to GRECO were the impetus to the development of the Russian legislation on combating corruption in general and in the field of disciplinary responsibility of regulation of municipal employees in particular.

The contradictions of Russia and GRECO on the types of responsibility and the rule of criminal liability for acts of corruption can be explained by the fact that disciplinary liability does not exclude other forms of accountability in Russia, including administrative and criminal. Disciplinary liability is only the initial link in the system of penalties for corruption offenses.

Under the influence of GRECO was tightened disciplinary responsibility in a conflict of interest on state and municipal service, and introduced additional layoffs base in connection with the loss of confidence. Types of disciplinary measures and dismissal of the content of the base of municipal and government officials in connection with the loss of confidence for corruption offenses must be standardized. 
Based on analysis it can be concluded that the system of legal regulation of corruption counteraction in the Russian Federation is formed, operates and is developing rapidly. The recommendations of GRECO have a significant impact on its modernization. GRECO recommended to review the system of administrative and criminal procedures in order to firmly establish that cases of corruption are to be treated as criminal offences as a main rule. In Russia, the National Anti-Corruption Plan has been created for 2016-2017, it provides tougher penalties for corruption-related crimes. GRECO commends the authorities for having initiated a systematic evaluation of the levels of corruption in the Russian Federation and of the efficiency of the anticorruption measures taken through means, such as regular sociological research. It also acknowledges the introduction of a comprehensive and on-going assessment of the application of laws, particularly in order to ascertain their efficiency in combatting corruption. The involvement of and the contribution to such monitoring by a large group of state bodies is a welcome development. As concerns civil society's input, GRECO appreciates that a specific provision has been made for its participation in the anti-corruption monitoring and, in particular, that some solid foundations are being laid down for the engagement between the public authorities and representatives of the Russian business community. Overall, it would appear that systems for monitoring in a comprehensive, objective and on-going manner of the levels of corruption in various sectors and of the anticorruption measures taken are in place, although co-operation with civil society would need to be further developed.

Bringing municipal employees to disciplinary liability for breach of duty in observance on combating corruption legislation of the Russian Federation does not exclude the perpetrators are being brought to administrative and criminal liability and is aimed primarily at the application of priority measures to prevent corruption.

At the same time, a number of legislative reforms remain to be completed. These relate, in particular, to the planned amendments to the Federal law "On Combating Corruption" (which are to ensure that acts of corruption are to be considered, as a main rule, as criminally punishable), to the Criminal Code (which should make provision for the confiscation of proceeds from all corruption offences), as well as to the Civil Code (which are to prohibit gifts within the public administration).

First of all, such penalty as moral condemnation is legally uncertain, but at the same time allowed as a measure of the impact on municipal employees for violation of the Model Code of Ethics and Official Conduct. The rules of law are not set its shape issuance or expiration date, no possibility of appeal. Moral condemnation is not a disciplinary action, but entails negative legal consequences, as taken into account in evaluating, formation of personnel reserve for promotion to higher positions, as well as the imposition of disciplinary sanctions.

To overcome the gap of legal regulation is necessary to define the legal status of moral condemnation, as well as the form of its issuance, validity and legal consequences. The Model Code of Ethics and Official Conduct of Civil Servants of 
the Russian Federation and Municipal Employees is expedient to provide that moral judgment is used to meet the requirements of the Code of Ethics.

Secondly, the first line of defence against corruption at the local government level will be effective prevention, detection, and control programs. Despite the many and sometimes complex forms in which corruption comes, there are steps that can be taken at the local government level to prevent and reduce its influence. Diagnostic procedures can be used to identify areas where corruption is especially likely or may already have taken hold. Codes of conduct may clarify expectations about official integrity and reduce situations of conflict of interest, while systematic management procedures may enhance employee oversight.

Thirdly, other key elements in the prevention of corruption may include strong public disclosure of government information, independent external monitoring and effective internal monitoring, anticorruption education and training (including training in professional ethics, recommendations and consultation services provided for officials, and accessibility to the public), scientific and efficient investigation mechanisms, and judicial and severe punishments for corruption.

Formalized guidelines, such as codes of ethics, regarding outside financial interests, gifts and favors, treatment of information, outside employment, respect for professional judgment, political activity, and other aspects of public behavior establish formal guidelines for ethical behavior and help cut down on the ambiguity that can attend individual consideration of ethical rights and wrongs.

Russian authorities nowadays continue building the momentum of such vital anticorruption mechanisms as the effective judicial control over public administration, the unimpeded access to public information, the reporting of corruption and protection of whistle-blowers. Without a doubt, the implementation and monitoring of impact of such measures should continue to feature prominently in the national anti-corruption action plans, including by ensuring input by civil society.

\section{References}

Akanle O. \& Adesina J.O. Corruption and the Nigerian Development Quagmire: Popular Narratives and Current Interrogations, 31(4) Journal of Developing Societies 421 (2015).

Beeri I. \& Navot D. Local Political Corruption: Potential Structural Malfunctions at the Central-Local, Local-Local and Intra-Local Levels, 15(5) Public Management Review 712 (2013).

Clausen Bianca et al. Corruption and Confidence in Public Institutions: Evidence from a Global Survey, 25(2) The World Bank Economic Review 212 (2011).

International Encyclopedia of Comparative Law. Vol. 6 (The Hague: Martinus Nijhoff Publishers, 1972).

Škrbec J. \& Dobovšek B. Corruption Capture of Local Self-Governments in Slovenia, 11(3) Lex Localis - Journal of Local Self-Government 615 (2013). 
Treisman D. The Causes of Corruption: A Cross-National Study, 76 Journal of Public Economics 399 (2000).

\section{Information about the authors}

Hugo Flavier (Bordeaux, France) - Associate Professor of Public Law and European Law, University of Bordeaux, Centre for Research and Documentation in European and International Law (CRDEI) (16 Avenue Léon Duguit, Pessac, 33608, France; e-mail: hugo.flavier@gmail.com).

Irina Chikireva (Tyumen, Russia) - Associate Professor, Labor and Commercial Law Department, Tyumen State University (38 Lenina St., Tyumen, 625003, Russia; e-mail: chikireva777@mail.ru).

Kseniya Ivanova (Tyumen, Russia) - Associate Professor, Constitutional and Municipal Law Department, Tyumen State University (38 Lenina St., Tyumen, 625003, Russia; e-mail: k.a.ivanova@utmn.ru). 